\title{
Indigenous Principles of Wild Harvest and Management: An Ojibway Community as a Case Study
}

\author{
Chantel M. LaRiviere $\cdot$ Stephen S. Crawford
}

Published online: 29 September 2013

(C) The Author(s) 2013. This article is published with open access at Springerlink.com

\section{Introduction}

In colonial nations such as Canada, there have been increasing requirements for governments to engage directly with Indigenous communities regarding their rights and interests in natural resource management generally, with specific focus on the role of Indigenous knowledge systems in harvest management decision-making (Tikina et al. 2010). Canadian courts have repeatedly focused on two factors with extremely important consequences for the Nation-to-Nation relationships that exist between the Crown and the Indigenous communities: (1) Indigenous rights must be reconciled with other government responsibilities including justified infringements for the often ill-defined concept of 'conservation' (Crawford and Morito 1997; Ayers 2005; Nadasdy 2005), and (2) the 'honour of the Crown' must be maintained when consulting Indigenous communities, especially with regard to management decision-making about their natural resources (Morito 1999; Slattery 2005). Given the legal necessities for a Eurocentric government to engage in honorable and meaningful consultation with Indigenous communities about conservation ethics and natural resource management, it remains to be seen how these Indigenous-Western science cross-cultural consultations should be undertaken (Crawford et al. 2010). The trend to date has largely been the domination of Western Science over Indigenous knowledge systems (in the sense described by Pentland 1995); circumstances in which Indigenous knowledge holders might be requested to provide information to scientists/managers who would evaluate it for reliability and utility before deciding whether to incorporate in a science-based management program (McGregor 2004;

C. M. LaRiviere $\cdot$ S. S. Crawford $(\bowtie)$

Department of Integrative Biology, University of Guelph,

Guelph, Ontario N1G2W1, Canada

e-mail: scrawfor@uoguelph.ca
Clark and Slocombe 2009; Lyver et al. 2009). Some scholars have suggested that conflict caused by this kind of cultural domination could be reduced if governments and Indigenous communities re-initiated their discussions with an examination of similarities and differences in principles regarding 'conservation' and 'natural resource management' (Ratner and Holen 2007; Ebbin 2011; Watson et al. 2011). In this way, the communities could develop a structured and respectful dialogue about wild harvest management in the spirit of reconciliation and productive collaboration.

There have been numerous attempts by Western scientists to reach internal consensus on general principles for natural resource management (Holt and Talbot 1978; Christensen et al. 1996; Mangel et al. 1996; Dale et al. 2000), habitat management (Lindenmayer and Nix 1993; Botsford et al. 2003; Naiman and Latterell 2005), harvest management (FSC 1996; Heissenbuttal 1996; Lauck et al. 1998; Fowler 2003; FAO 2001; González-Laxe 2005; Utne 2006; Shelton and Sinclair 2008; Francis et al. 2007; MSC 2010) and biodiversity/endangered species management (Walters 1991; Tilman 1999; Ebbin 2011).

Although the practice of 'defining principles for resource management' is not something that Indigenous societies typically engage in, there have been many attempts to survey and understand Indigenous values and social norms in this regard (Ratner and Holen 2007; Turner and Berkes 2006; Watson et al. 2011). For example, Alcorn (1993) offered a general treatise on the relationship between Indigenous worldviews and the Western idea of 'conservation.' Berkes et al. (1998) explored fundamental properties of ecosystem-like concepts in Indigenous cultures. In the 2011 'Principles of Tsawalk, Umeek (E. Richard Atleo), a hereditary Nuu-Chah-Nulth chief, discussed his culture's principles of Recognition, Consent, and Continuity and their important role in maintaining balance - in contrast to the global consequences of Western 'sustainable' development. Prober et al. (2011) 
characterized the principles of Australian Aboriginal ecological calendars and indicators and evaluated their possible interaction with Western social-ecological systems for natural resource management.

Over the past decades, a growing body of communitybased collaborative studies has provided more depth and insight into the structure and function of traditional Indigenous knowledge systems and their associated decision-making processes for harvest management (e.g., Feit 1986; Brightman 1993; Horstman and Wightman 2001; Ayers 2005; Castleden et al. 2009; Lyver et al. 2009; Moller et al. 2009; Bilbao et al. 2010). However, as Jones et al. (2010) caution, researchers must always be careful to consider Indigenous community-based value systems as spatially and temporally local expressions of their culture. Efforts to identify general Indigenous 'principles' of natural resource management must be tempered by conscious recognition that (1) 'principles' are social constructs which are deeply embedded in cultural and social norms that are typically complex and subtle to the outsider (Houde 2007; Peloquin and Berkes 2009), and (2) Indigenous cultures and worldviews are inherently more diverse than the relatively homogenous standards of Western science (although see a provoking challenge of this assumption about scientific homogeneity by Watson-Verran and Turnbull 1995).

The goal of our investigation was to develop and demonstrate a process for engaging with Indigenous communities to inquire about the structure and function of social norms in their culture that could relate to Western 'principles' for natural, renewable resource management. In order to achieve this goal, we worked in partnership with a sponsoring Ojibway community on a case study to employ community-based, participatory research methods with traditional people who were most familiar with social norms for harvest management.

\section{Methods}

This research employed a case study approach with the Chippewas of Nawash Unceded First Nation, hereafter referred to as Nawash, the home community of the first author. A research proposal for this investigation was reviewed and approved by Nawash Band Council, who appointed a male Elder to serve as Liaison, to ensure that the implementation of methodologies was culturally appropriate for the community. The methods for this research project were reviewed and approved by the University of Guelph Research Ethics Board.

Nawash and the Chippewas of Saugeen First Nation, collectively referred to as the Saugeen Ojibway Nation, share a series of distinctive treaties signed with the Crown in the mid- 1800s that are recognized among the most clearly proven rights of Canadian First Nations (Blair 1997, 2000; Walters 1998). Their traditional territories (Fig. 1) comprise a land area of $6,500 \mathrm{~km}^{2}$ extending from the Saugeen (Bruce) Peninsula into southern Ontario, as well as numerous tributaries, and more than $500 \mathrm{~km}$ of shoreline and $10,000 \mathrm{~km}^{2}$ of Lake Huron extending offshore into both the Main Basin and Georgian Bay (Lytwyn 1992; Morito 1999). The Saugeen Ojibway Nation also have exclusive harvesting rights in a 930 ha hunting reserve on the northern Saugeen Peninsula, as well as an exclusive commercial fishing reserve negotiated with the Crown in Lake Huron extending north from central Main Basin, around the Saugeen Peninsula and associated Fishing Island, and east to the middle of southern Georgian Bay. The Nawash reserve itself is approximately $64 \mathrm{~km}^{2}$ in land area, located at Neyaashiinigmiing; an Ojibway name translating roughly to "point of land covered on three sides by water" commonly referred to in English as Cape Croker (Borrows 1997; Keeshig-Tobias 1996). The on-reserve population of Nawash is approximately 700 people, while the off-reserve population is approximately 1,500 people (Chippewas of Nawash Band Council Membership Office, Iris Ashkewe, pers. comm. 2009).

A case study approach was used in this investigation because it provided the best opportunity for in-depth exploration of the socially constructed nature of an Ojibway knowledge system - especially the structure and function of fundamental principles used in resource management (Nakashima 1993; Turner et al. 2000; Kendrick and Manseau 2008). Nawash was a natural choice for this case study because (a) the community has a long history of interactions (both collaborative and conflicted) with Western scientists/managers over numerous natural resource issues (Borrows 1997; Akiwenzie and Roote 2004; Koenig 2005), and (b) Nawash sponsors the second author's biology faculty position at the University of Guelph, including responsibilities to undertake research aimed at improving relations between Indigenous and Western science knowledge systems.

Since time immemorial, the Nawash people have lived in their traditional territories and participated in wild harvest management activities for sustenance, ceremony and commerce (Lytwyn 1990; Johnston 1995; Borrows 1997; Blair 2000). Nawash harvests have included a high diversity of wild food/medicinal plants, as well as fishes (including lake whitefish, lake trout, lake sturgeon, herring), birds (including ducks, ruffed grouse, geese), and mammals (including white-tailed deer, northern raccoon, black squirrel, North American porcupine, snowshoe hare, eastern cottontail rabbit). Nawash also has a long history of trapping American beaver, river otter, common muskrat, pine marten and fisher for food and/or commerce. A complete list of English, Ojibway and scientific names for these species can be found in Appendix 1. 
Fig. 1 Traditional territory of the Saugeen Ojibway Nation (collectively the Chippewas of Nawash Unceded First Nation and Saugeen First Nation) in southern Ontario Canada and Lake Huron/Georgian Bay of the Laurentian Great Lakes

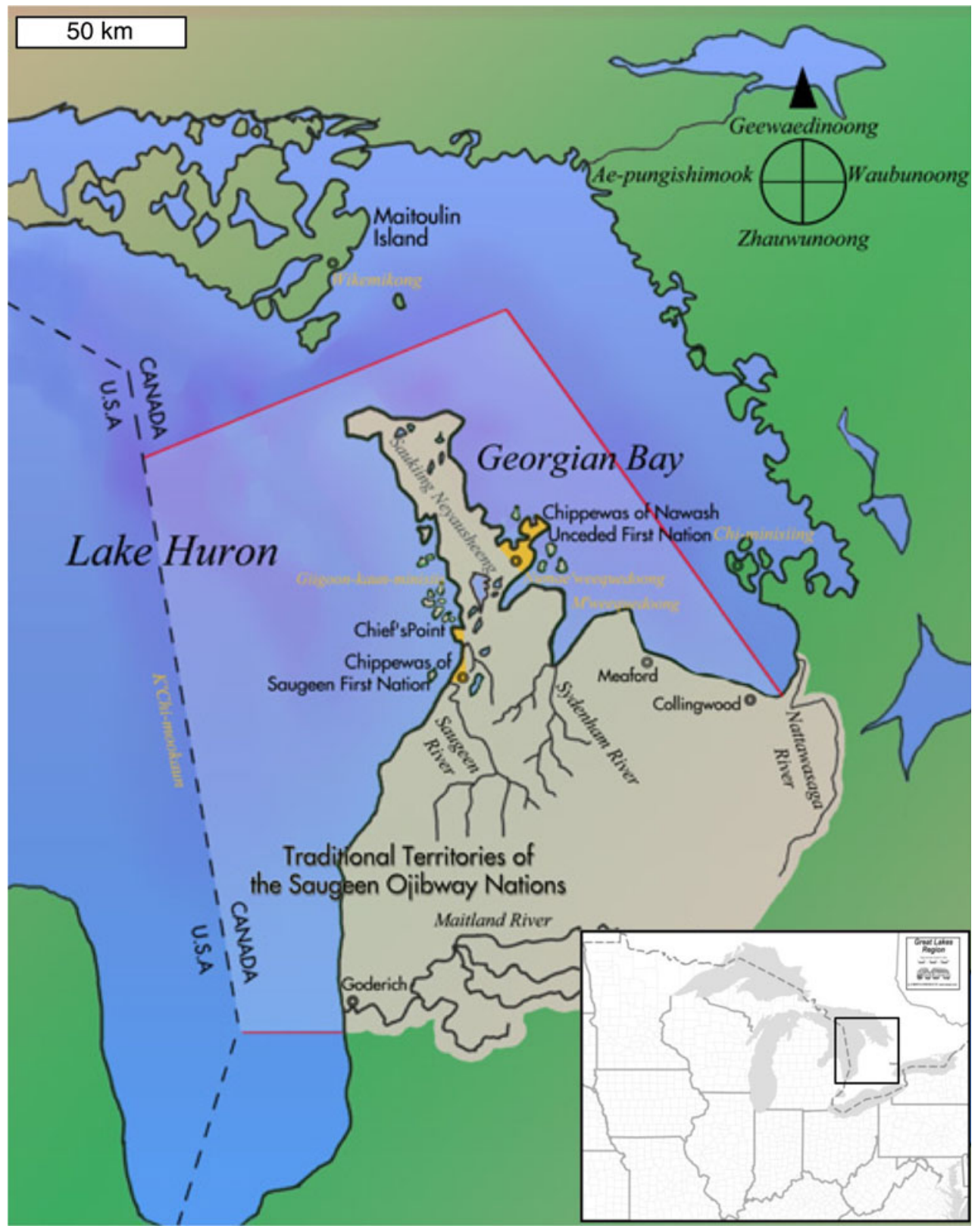

To ensure that our research engaged knowledgeable community members, we used methods proposed by Davis and Wagner (2003) and Sillitoe et al. (2005). First, a survey form (Appendix 2) was distributed to each member of Nawash Council and the Liaison in Spring 2007, requesting them to help identify on-reserve Nawash community members who were considered to be most knowledgeable about traditional Ojibway practices pertaining to the harvesting of wild plants and animals. Knowledge holders were also identified during interviews with other knowledge holders; this snowballing process is considered to be especially important in highly embedded knowledge systems (Davis and Wagner 2003).

The interviewer made frequent preliminary visits (approximately bi-weekly) to the community throughout the winter and spring of 2007 in order to encourage a general sense of familiarity with the project and the investigators (Smith 1999). Formal introductions to knowledge holders were made by the Liaison prior to any request for an interview. During these introductions the Liaison identified the interviewer as a Nawash band member who had grown up off-reserve, and discussed the context and purpose of the research project with knowledge holders. Every effort was made to ensure that community members felt like research partners engaged in a relationship of trust (Santiago-Rivera et al. 1998; Smith 1999; Schnarch 2004); this trust was particularly important since participants were asked to share knowledge and beliefs that were potentially intimate (Brant Castellano 2004). 
During the course of research, the primary author frequently participated in a variety of harvest-based activities including medicinal and food plant collecting, fishing, hunting, and trapping. These activities were initiated by the Liaison, and were designed to create an array of situationbased learning experiences for the primary author. These experiences provided the primary author with an opportunity to directly experience Ojibway harvesting, and created a shared sense of experience which was frequently drawn upon during knowledge holder interviews.

We employed a semi-structured interview technique during Initial and Follow-up phases of the study, to create an informal and conversational atmosphere that facilitated flexible and open-ended discussion (Grenier 1998). Initial interview questions were general in nature, and designed to elicit discussion about traditional wild harvest/management. Follow-up interviews were designed to extend discussion specifically on harvest/management principles that had been collectively identified by knowledge holders during the Initial interviews. Interview guides with predetermined but open-ended questions (Appendix 3) were provided to knowledge holders at the beginning of each interview, and were used to keep discussions focused, yet open to unanticipated knowledge (Huntington 1998; Sillitoe et al. 2005). Knowledge holders were asked if they had a preference regarding interview recording method (digital voice recorder-default, hand-written notes), and all subsequent discussions were recorded in a consistent manner, and then transcribed in full

The digital knowledge base software program NVivo Version 7.0.247.0 SP2 (Copyright QSR International Pty. Ltd. 1999-2006) was used to organize, code, and interpret transcribed data derived from both Initial and Follow-up interviews. Depending on the specific context of a knowledge holder discussion, nodes were created for phrasessentences-passages that made some reference to knowledge systems, natural history, practices or principles related to wild harvest and/or management. For the purpose of this study, 'principles' were defined as general concepts that are held to be true by the community members; concepts that could be either causal principles in the sense of explanations of cause-effect mechanisms (i.e. Western science 'hypotheses') regarding the states of nature, or moral principles in the sense of guiding factors formulated as general rules of conduct that promote the satisfaction of particular values (Crawford and Morito 1997).

\section{Results}

Eight knowledge holders were first identified by Nawash Council/Liaison; the snowballing technique with knowledge holders also identified most of these persons, as well as an additional two knowledge holders, for a total of ten knowledge holders interviewed in this study. This group of knowledge holders included seven men and three women, ranging in age from 37 to 95 years.

A total of $17.5 \mathrm{~h}$ of interviews were conducted with the Nawash knowledge holders during the period from September 2007 to May 2008 (Table 1). Initial interviews were conducted over $11.5 \mathrm{~h}$ with the complete set of ten knowledge holders, ranging in duration from 0.75 to $1.50 \mathrm{~h}$ $(1.15 \pm 0.29$, mean \pm s.d. $)$. Six of the knowledge holders preferred hand-written interview notes, while the remaining four expressed no preference and were recorded using a digital voice recorder. Follow-up interviews were conducted over $6.0 \mathrm{~h}$ with six of the ten knowledge holders, ranging in duration from 0.50 to $1.75 \mathrm{~h}(1.00 \pm 0.52)$. Sadly, three knowledge holders passed away during the 10 month interview period of this study. There did not seem to be an appropriate time to re-engage with the other outstanding knowledge holder.

A total of 154 references to moral or causal principles of harvest/management were made by the knowledge holders during the Initial interviews. After closely examining the context within which individual knowledge holders had made these references, it seemed clear to us that there were repeated instances of five distinct principles. Table 2 presents the name and a selection of quotation/paraphrase text from different knowledge holders that we considered to be representative of the five identified principles.

The principle of SEASONally based harvesting implies that harvesters adhere to SEASONal cues that alert Ojibway people of the temporal availability of particular resources.

Table 1 Summary of semi-structured interview recording method and duration with ten traditional Knowledge Holders from the Chippewas of Nawash Unceded First Nation

\begin{tabular}{|c|c|c|c|c|}
\hline \multirow{2}{*}{$\begin{array}{l}\text { Knowledge } \\
\text { Holder }\end{array}$} & \multicolumn{2}{|c|}{ Initial Interviews } & \multicolumn{2}{|c|}{ Follow-Up Interviews } \\
\hline & $\begin{array}{l}\text { Recording } \\
\text { method }\end{array}$ & $\begin{array}{l}\text { Duration } \\
\text { (hr) }\end{array}$ & $\begin{array}{l}\text { Recording } \\
\text { method }\end{array}$ & $\begin{array}{l}\text { Duration } \\
\text { (hr) }\end{array}$ \\
\hline A & DVR & 1.50 & DVR & 1.50 \\
\hline B & HWN & 0.75 & & \\
\hline $\mathrm{C}$ & $\mathrm{HWN}$ & 1.25 & & \\
\hline $\mathrm{D}$ & HWN & 1.00 & HWN & 0.75 \\
\hline $\mathrm{E}$ & HWN & 1.25 & & \\
\hline $\mathrm{F}$ & HWN & 1.50 & HWN & 1.00 \\
\hline G & HWN & 1.00 & & \\
\hline $\mathrm{H}$ & DVR & 0.75 & DVR & 0.50 \\
\hline I & DVR & 1.50 & DVR & 1.75 \\
\hline $\mathrm{J}$ & DVR & 1.00 & DVR & 0.50 \\
\hline Total & & 11.50 & & 6.00 \\
\hline
\end{tabular}


Table 2 Selected descriptions of wild harvest/management principles identified from interviews with traditional Knowledge Holders from the Chippewas of Nawash Unceded First Nation

Principle name Principle descriptions (Knowledge Holder Code)

(Type)

SEASONS (Moral - "The life of our people, they were guided by the seasons so that there were only certain activities conducted in each season, like and Causal) the fall season was harvest time, the spring time was new life, and so because there was new life there, especially young being born and so forth, they wouldn't bother with those creatures because those creatures are being renewed and they're newborn so to make sure that they are going to be sustainable, you never kill a deer that's carrying her young, things like that." $(J)$

- "At certain times we knew that we don't go hunting because of the reproduction, because you have to let wildlife and fish reproduce." (E)

- "In the fall we had whitefish. We also had them in the summer (whitefish); they'd come to shore. They spawned in June. That was seasonal." (G)

NEEDS (Moral - We were always told not to take more than you need. You don't go out and fill up ten freezers. You always looked ahead and and Causal) say I know that I am going to be giving some away. (E)

- We used common sense in deciding how much to take, for example, you don't destroy what you eat and you only take what you can use, share or cure. (F)

- "Just because the fish is there you didn't fish to the extreme where you caught more than you could actually use." (H)

THANKS (Moral) • Everyone gives thanks in their own way, its part of the culture. (C)

- "You'd leave tobacco where you killed the animal or some other token that you had with you but it was mostly tobacco. It meant that you were thanking Mother Nature for the provision of food and then you are also giving thanks for that animal giving its life for your existence, that's what it meant." (A)

- "Grandma used to put tobacco down when they got sweet flag." (D)

WASTING (Moral • "We were always told what you kill you eat because it was given to you for food and it was there for a purpose so we didn't waste." (A)

and Causal) - It comes back to you because it haunts you, because now, you've left that animal out there to rot. You've left that thing out there to rot, and that's what haunts you, you shouldn't have done that. You shouldn't have, if you weren't going to use it, why kill it. Let it be, it has a right to live too, just like anything else has a right to live. A bird has a right to live, and trees have a right." (A)

- "You were obligated not to waste in some fashion. Because if you wasted, it was always thought that it was less for the next time around or the next person in line." $(\mathrm{H})$

- "I know even parts of the fish, like take the sucker for example... it had a lot of bones but we used to take the bones out and make fish pie out of it. And then there was sucker heads that were used to make fish soup. Every part of the heads was consumed and all the bones that were left were the jaw and the facial bones. Even the eyes were floating around in the soup. I remember my parents really liked sucker head soup. Even the eggs were good to eat too, the sucker eggs." (J)

SHARING - Always share if you get fish or animals. (D)

(Moral) - "I remember I got four moose that one year. Far too many eh. A few of us went and we got four moose. So I spent all day cutting it up and just called the people, come and get moose, come and get moose." (I)

- "Most of them I think used to hunt for their family and then if there was any extra it was given out to the community or the Elders that would like some but didn't have a chance to get any." $(\mathrm{H})$

- "The community used to be a food bank. You never used to have to go to the community to get your 2 bags of groceries. It would be on the porch secretly, or sometimes people would go around the community and collect what people could spare for others they knew to be in need." (Liaison)

For example, the first warm rains in the spring might bring to the Ojibway mind images of the first wild leeks or wild mushrooms emerging from forest soils, just as the appearance of fireflies in late May or early June may serve to remind the Ojibway that the wild strawberries are ripe and the birch bark is ready to be harvested (Liaison, pers. comm. 2007). The SEASONS also serve to remind Ojibway people as to the appropriateness of harvesting particular resources at particular times within each season (Knowledge Holder J). For example, Ojibway people do not hunt for deer and other mammals when females may be carrying or nurturing young, however, they know that when the leaves begin to turn in the fall that they can safely hunt for deer without endangering the newly born (Driben et al. 1997). The SEASONS principle was classified as moral due to the consideration of appropriateness of harvesting in-season, however this principle was also classified as causal since some of the knowledge holders linked season-based harvesting to underlying biological or ecological cycles of harvested species.

The NEEDS principle described harvesters' effort in relation to the abundance or availability of the target plant or animal species. It was important that a harvester not succumb to temptation in cases where they had the 
opportunity and the means to harvest more than what was required to satisfy current needs of their family/community. In this study, the NEEDS principle was also classified as both moral and causal, in this case because some of the knowledge holders linked harvester restraint to the ability of the supporting populations of harvested plants/animals to regenerate for continued existence, and the prospect of sustained future harvests. Several Nawash knowledge holders expressed the need for caution in determining how much to harvest in contemporary situations, because recently created or improved technologies such as refrigeration and dehydration enable harvesters to accumulate far beyond their immediate needs.

The THANKS principle was described by knowledge holders who stressed the moral imperative for harvesters to consciously and actively express gratitude for their good fortune in receiving desired plants/animals. This gratitude could be directed to the Creator and/or the organism that gave its life to the harvester. Gratitude could be expressed in various ways, however many of the knowledge holders stressed the importance of expressing gratitude in traditional Anishnaabe manners, especially those involving the respectful offering of tobacco (Hallowell 1960).

The WASTING principle focused on the abhorrence of disrespecting the plants/animals that had offered their lives to the harvester. Specifically, it was the harvester's moral obligation to make maximum use of the gift that had been received, rather than taking only premium organisms that had been killed, or using only premium parts of the organism's body. This principle was also classified as causal, because some of the knowledge holders linked the effects of not WASTING with the idea that such a strategy would reduce harm to the supporting population, and thus increase the opportunity of future harvests.

The SHARING principle reflected the expectation that harvesters would provide some or all of their harvests to members of their extended family, other members of the community, or anyone who was in need of such provisions. The SHARING principle was strongly related to the idea that the harvested plants/animals do not 'belong' to the harvester, but rather give themselves to the people so they may also survive and flourish.

Table 3 presents frequencies at which the ten knowledge holders referenced the five identified principles during Initial interviews. The principles are organized horizontally in decreasing frequency across knowledge holders, while the alphabetic codes of specific knowledge holders are organized vertically in decreasing frequency across total number of principle references. The cumulative number of references made by all knowledge holders to each of the five identified principle ranged from 29 to 34 with a mean of 30.8 ( \pm 2.2 s.d.). The total number of references to principles made by individual knowledge holders during an individual interview ranged from 7 to 26, with a mean of 15.4 ( \pm 7.0 s.d.). For each knowledge holder, the number of references per principle ranged from 0 to 8 with a mean of $3.1( \pm 2.0$ s.d.). It is interesting to note that 6 of 10 knowledge holders made reference to all five of the identified principles; the remaining knowledge holders (B, I, G and D) still made reference to most of the principles, despite making the fewest references of all knowledge holders in the group.

\section{Discussion}

In this study, we identified five major principles about traditional Ojibway harvest/management expressed by ten Nawash knowledge holders over $17.5 \mathrm{~h}$ of semi-structured interviews. While we believe this small sample can provide insight into the structure and function of Indigenous knowledge systems, we are under no illusions that the sample is representative of the traditional principles that exist within Nawash or Ojibway culture. The principles that we identified in this study reflect only what the knowledge holders chose to share with us at the time and in the specific context of the interviews. We explicitly recognize that it can be very difficult for these concepts to remain intact through the processes of cultural and language translation; as Ingold and Kurtilla (2000) caution, the lack of Indigenous articulation of 'principles' under these kinds of interview conditions does not necessarily mean the concepts did not exist. In the future, community-based research focusing on principles of resource management should employ some means of detecting an asymptote in the number of new principles identified during interviews, similar to the sampling designs used by ecologists to estimate the number of undiscovered species in an ecosystem (e.g., Chao et al. 2009).

The abundance and distribution of principles expressed by Nawash knowledge holders were remarkably consistent. Most interviewees made relatively equal references to most (if not all) of the five identified principles, suggesting that these principles derive from a general set of values that permeate through the traditional community. Despite incidental comments from community members about traditional people with specialized knowledge, we did not find causal or moral principles that were specific to certain individuals or particular kinds of harvesting. It could be that more specialized principles require additional detail in the semistructured interview format, including greater focus on particular kinds of harvesting or management situations (e.g., seining whitefish, trapping beaver, shooting grouse).

We were also interested to note that all five of the identified principles could be considered moral precepts; two of which were classified as solely moral (THANKS, SHARING), while three were classified as having both moral and causal characteristics (SEASONS, NEEDS, WASTING). The causal 
Table 3 Frequency of references to five identified principles of wild harvest/management made during Initial interviews with traditional Knowledge Holders from the Chippewas of Nawash Unceded First Nation

Bold numbers are summary statistics, rather than test statistics

\begin{tabular}{|c|c|c|c|c|c|c|c|}
\hline \multirow{2}{*}{$\begin{array}{l}\text { Knowledge } \\
\text { Holder }\end{array}$} & \multicolumn{7}{|l|}{ Principles } \\
\hline & SEASONS & NEEDS & THANKS & WASTING & SHARING & Subtotal & Percent \\
\hline $\mathrm{J}$ & 8 & 6 & 4 & 5 & 3 & 26 & 16.9 \\
\hline A & 6 & 4 & 7 & 4 & 3 & 24 & 15.6 \\
\hline $\mathrm{H}$ & 5 & 5 & 3 & 5 & 5 & 23 & 14.9 \\
\hline $\mathrm{F}$ & 3 & 5 & 5 & 2 & 3 & 18 & 11.7 \\
\hline $\mathrm{C}$ & 5 & 4 & 2 & 4 & 1 & 16 & 10.4 \\
\hline $\mathrm{E}$ & 1 & 1 & 5 & 1 & 4 & 12 & 7.8 \\
\hline B & 2 & 2 & 1 & 5 & 0 & 10 & 6.5 \\
\hline I & 2 & 2 & 0 & 1 & 5 & 10 & 6.5 \\
\hline G & 2 & 0 & 2 & 2 & 2 & 8 & 5.2 \\
\hline $\mathrm{D}$ & 0 & 3 & 1 & 0 & 3 & 7 & 4.5 \\
\hline Subtotal & 34 & 32 & 30 & 29 & 29 & 154 & \\
\hline Percent & 22.1 & 20.8 & 19.5 & 18.8 & 18.8 & & 100.0 \\
\hline
\end{tabular}

linkages identified by knowledge holders (i.e., harvesting season-ecological cycle, harvester restraint-population regeneration, maximum utility-minimum demand) were typically implied during conversations, rather than explicitly defined in linear cause-effect relationships. For example, while some knowledge holders expressed serious concern that killing pregnant deer during winter could have a strongly negative effect on the abundance of deer in the future, they did not make reference to specific concepts akin to population growth rates, density-dependence, or compensatory mortality. There are at least two possible explanations for the general lack of specific cause-effect principles about natural processes in this study. As described above, the limited breadth and depth of discussions may simply not have provided sufficient opportunity to trigger discussions about the processes underlying wild harvest and management practices. We suspect that causal principles may have emerged as a stronger topic of discussion if the interview sample had included a traditional person whose livelihood was still heavily dependent on their own intensive harvesting of wild plants and animals in the territory. However, it is also possible that, as suggested by Peloquin and Berkes (2009), traditional Ojibway knowledge of causal mechanisms does not take the form of abstract mental representations that could be recognized in this study as 'causal principles' in the Western cultural sense. From Feit's (1987) perspective, Cree hunters say that trends in the condition of harvested animal populations are signs of the quality/quantity of future harvests; however the traditional Cree are not scientists - they phrase their knowledge and predictions in a culturally distinctive system of concepts and values. Obviously the ramifications of such epistemological arguments are profound, and require active participation in the debate by members of the Indigenous knowledge systems in question (Davis and Ruddle 2010).
The natural resource management principles identified in this study are highly consistent with the descriptions of principles previously reported for Ojibway communities (e.g., Warren 1885; Hallowell 1955, 1960; Overholt and Callicott 1982; Borrows 1997; Driben et al. 1997) and for other Indigenous knowledge systems in Canada and throughout the world (e.g., Turner et al. 2000; Colding and Folke 2001; Turner and Berkes 2006; Metallic 2008).

The SEASONS principle has been reported in other Ojibway communities where harvesters avoid hunting for deer or other wildlife species when females could be carrying or nurturing young; hunting can resume without endangering young-of-the-year when the leaves begin to turn in the fall (Driben et al. 1997). Scheduling harvesting activities relative to critical life history periods of harvested organisms is practiced in many Indigenous societies (Colding and Folke 2001). Sami people in northern Finland intensively organize their migratory and harvesting efforts with annual seasonal fluctuations in temperature, precipitation and daylight hours - and the associated seasonal patterns in the distribution and abundance of the plants and animals upon which they rely (Bjørklund 1990; Ingold and Kurtilla 2000). Lyver et al. (2009) discussed alternate possible explanations for Māori principles regarding post-breeding harvests of kereru and titi, including coincidence of favorable circumstances and deliberate conservation planning. Prober et al. (2011) described ecological calendars and seasonal knowledge of Australian Aboriginal communities to predict environmental conditions, distribution and abundance patterns, migration pathways, and effectiveness of harvesting tactics. Recently there has been increased focus on Indigenous season-based principles, especially with regard to the enormous potential of global climate change to disrupt traditional capabilities to live off the land (Turner and Clifton 2009; Green and Raygorodetsky 2010). 
The NEEDS principle is also prevalent in other Ojibway and Indigenous communities (Borrows 1997; Driben et al. 1997; Knudtson and Suzuki 1992). Over-killing, which can be understood as killing beyond immediate needs, is harshly criticized in other Ojibway and Cree Nations (Driben et al. 1997). Brightman (2007) discussed the importance of this principle in the Cree stories of Wiisahkiicaah who taught the people about the 'wages of gluttony.' In Mi'kmaq culture, the principle of netukulimk serves the same kind of constraining function when harvesters find themselves in a rich environment that could provide more than their needs (Barsh and Youngblood Henderson 2003). Similarly, Zavaleta (1999) reported complex and species-specific restraint practices among Yup'ik waterfowl hunters in Alaska.

The THANKS principle is well known and deeply rooted in Ojibway natural resource harvesting and management as an important means of acknowledging relationships to the beings that sustain individuals in their daily life (Densmore 1928). Acknowledging these relationships in Ojibway culture can be as simple as leaving tobacco or offering a few words of thanks - something that directly reminds the harvester and consumer that all humans are connected to, and sustained by, the natural world (Johnston 1976; Metallic 2008). Māori offer THANKS to acknowledge the unity between all aspects of creation, as well as the specific energy that radiates from life (Marsden and Henare 1992). Many other Indigenous societies also give THANKS to spirit beings before and/or after harvesting activities (Knudtson and Suzuki 1992; Turner and Berkes 2006). In many Indigenous cultures, knowledge systems are grounded in reciprocal and spiritual relationships with plants, animals and the environment; there are strong social forces regarding the right ways and wrong ways of interacting with these spirits that sustain the community in more than physical ways (Tanner 1979; Feit 1986; 1987; Menzies and Butler 2006). McClellan (1975) identified the belief among the Tutchone and Kaska people of southern Yukon that appropriate respect for the animals is a precondition for continued success in the hunt. Brightman (1993) and Feit (1994) described the complex of Cree principles of respect and reciprocity for harvested animals, including the "same respect you give yourself" expressed variously as singing to the animals, verbal petition, quick killing to minimize suffering, ritual sacrifice and offerings. Berkes (1999) refers to a reciprocity 'ethic' - a state of mutual respect and exchange, in which all life exists on the same level, including humans. Within the terms of this ethic, humans are able to take plant or animal life for food because the organism gives itself to the human - the human reciprocates by respecting and honoring the organism.

The idea of WASTING a harvest is particularly unfavorable in Ojibway and other Indigenous communities with beliefs that plants, animals and other elements of creation possess their own spirits and have a right to live that is equal to that of humans (Driben et al. 1997; Turner and Berkes 2006). Brightman (1987) described the strong avoidance of wasting among traditional Algonquins in the Hudson Bay region; Tanner (2007) discussed the broader, spiritual and religious worldview within which Innu have concerns about wasting nutshimiu-natukun ('country medicine'). This antiWASTING principle is expressed in many different ways, but often takes the form of maximizing utility from as many parts of the harvested organisms as possible, with moral sanctions for those who take only 'premium' organisms or parts of organisms (Menzies and Butler 2006). Zavaleta (1999) noted that Indigenous hunters who practice waste avoidance reduce the likelihood of hunger when food is scarce, and also minimize the number of harvested animals necessary to meet the needs of hunter and community.

In Ojibway culture, the SHARING principle is based on the fundamental fact that no person in the community is permitted to claim ownership over a particular resource, thereby denying the use of this resource by others (Johnston 1976). Indigenous Nations generally identify with common resources that are shared in a manner that maintains and strengthen relationships within families, communities and territories (Metallic 2008). Perhaps the most well-known examples of the SHARING principle is evidenced in the practice of potlatch festivals/ceremonies in which Indigenous communities of the Pacific Northwest of America promote inter-dependence through the redistribution of natural resources (Knudtson and Suzuki 1992; Ayers 2005).

As investigators, we must constantly be mindful that these Indigenous 'principles' do not exist in isolation, but are embedded within the geographic and cultural and social conditions of community life. Consider, for example, the set of ethics and values presented by the Council of the Haida Nation to explain their worldview: Yahguudang (Respect), Giid tll'juus (Balance), Gina waadluxan gud ad kwaagiida (Interdependence), Isda ad diigii isda (Reciprocity), Gina k'aadang.nga gii uu tl' k'anguudang (Wise Counsel), 'Laa guu ga kanhllns (Responsibility) (Jones et al. 2010). Likewise, the work of Feit $(1986,1994)$ and Brightman (1993) with Cree communities reveals a profoundly interwoven and inter-dependent complex of spirituality, causality, reciprocity, and morality in the 'principles' of traditional hunters. Consider Brightman's (1993) description of the 'grateful prey:'

"The event of killing an animal is not represented as an accident or a contest but as the result of a deliberate decision of the animal or another being to permit the killing to occur. The dream events that Crees say prefigure successful kills are sometimes talked about as signs that this permission has been given. In waking experience, the decision finds culmination when the animal enters a trap or exhibits its body to the hunter for a killing 
shot. Since the soul survives the killing to be reborn or regenerated, the animal does not fear or resent the death. The animals' motivations for participating in these events of killing are figured both in the idioms of love and of interest. Animals may "pity" the hunters who have need of their flesh, and especially is their benevolence evoked when the hunter complies with the conventional objectifications of "respect," treating the carcass, meat, and bones in the correct fashion. Conversely, ritual omission or blasphemy angers the animals, who then withhold themselves. But the role of the hunter-eater is not that of passive recipient only, and the animals themselves stand to gain from the exchange. Having received the gift of the animal's body, the hunter reciprocates. Animal souls are conceived to participate as honored guests at feasts where food, speeches, music, tobacco, and manufactured goods are generously given over to them. Hunter and prey are thus successively subject and object in an endless cycle of reciprocities. Ultimately, the roles of human and animal are complementary, for each gives life to the other. The treatment of the remains not only objectifies respect but is said to restore the animal to a living condition." (Brightman 1993, p.187)

Clearly, within traditional Indigenous knowledge systems much of the so-called objective knowledge-including what Western people call causal principles-are framed within a moral and spiritual context. This context may seem to be very different from the detached and abstract causal principles that drive the Western science knowledge system, until we peel back the layers to find the implicit and deep morals that also exist within Western science (Castleden et al. 2009; Buijs 2009). Within this moral context, Atleo (2011) challenges us to consider the question "How much can humans know about reality?" The social structure of Indigenous and Western knowledge systems requires the indirect and direct action of values; these values affect the questions that are posed, the manner that investigations are designed and approved, and the manner that scientific discoveries become applied (Allchin 1999). The multi-faceted relationship between science and ethics is especially important as it relates to the standards of ethical conduct within science-honesty, carefulness, openness, freedom, and credit (Resnick 1998). Rollin (2006) explored the ideological agnosticism that many scientists subscribe to, with special reference to problems caused when ethical issues in science are ignored. While the vast majority of scientists will never have to confront major ethical or moral dilemmas associated with their research (e.g., Teller 1998), there is an emerging recognition among scientists that they have a profoundly reciprocal relationship with morality (Harris 2010). If western scientists were prepared to engage directly on moral issues - starting with their own beliefs and values - they would be much better prepared to recognize the intertwining causal and moral principles that exist within Indigenous knowledge systems (Ingold 2000; Morito 2002).

Given the modern legal requirement for meaningful consultation with Indigenous communities regarding natural resource harvest/management, it is difficult to imagine that such consultation could begin anywhere except by going back to the beginning - with Indigenous and Western science communities re-introducing themselves as people, their worldviews, and their knowledge systems. It is reasonable to expect that causal and/or moral principles would emerge naturally among the substantive points of discussion between Indigenous and Western science knowledge systems (Ratner and Holen 2007). If the local knowledge holders from both cultures recognize similarities in their principles, then these principles could be codified in more formal agreements and protocols between the parties. If the local knowledge holders recognize differences in their principles, then the parties would have to discuss how these differences can be respected and accommodated.

Is it possible to develop a framework for cross-cultural discussion that would enable Indigenous and Western science knowledge holders to engage meaningfully with each other's set of beliefs, practices and values? Was Callicott (1991) correct when he claimed that all systems of resource management are practical expressions of underlying principles? If so, then we think that Indigenous and Western science knowledge holders are obliged to actively search for these principles, and to make sure that they communicate them effectively to each other. If not, then Indigenous and Western science knowledge holders will have to keep searching for other bridges that will enable meaningful and reciprocal consultation on natural resource management issues. Either way, it seems clear to us that there could be much more to discuss in principle than either community might have originally expected.

Acknowledgments We honour the late Chief Ralph Akiwenzie, and thank Nawash Council and the Community of the Chippewas of Nawash Unceded First Nation for sponsoring this research project. We are especially grateful to the traditional knowledge holders who shared their time and wisdom with us. Special thanks to Anthony Chegahno and Daniel Keeshig for providing assistance with cultural context and community relations. Deb McGregor, Dan Longboat, and Tom Nudds provided superb scholarly guidance as members of the thesis Advisory Committee. This research was supported by research grants from the Social Sciences and Humanities Research Council of Canada, and the Casino Rama Award for Excellence Program.

Open Access This article is distributed under the terms of the Creative Commons Attribution License which permits any use, distribution, and reproduction in any medium, provided the original author(s) and the source are credited. 


\section{Appendix 1}

List of species names (English, Scientific, Ojibway) referenced in this investigation

\begin{tabular}{|c|c|c|}
\hline English name & Scientific name & Ojibway name \\
\hline American beaver & Castor canadensis & Ahmik \\
\hline $\begin{array}{l}\text { American black } \\
\text { bear }\end{array}$ & Ursus americanus & Mukwa \\
\hline American mink & Mustela vison & Zhongwyzh \\
\hline Atlantic salmon & Salmo salar & \\
\hline Bald eagle & Haliaeetus leucocephalus & Migisi \\
\hline Black squirrel & Sciurus carolinensis & Makade \\
\hline Bloater & Coregonus hoyi & \\
\hline Carp & Cyprinus carpio & Niigijiinh \\
\hline Chinook salmon & Oncorhynchus tshawytscha & \\
\hline Cisco spp. & Coregonus spp. & Bemidewishkawed \\
\hline Coho salmon & Oncorhynchus kisutch & Maazhi-namegos \\
\hline Common muskrat & Odatra zibethicus & Wazhushk \\
\hline $\begin{array}{l}\text { Common } \\
\text { strawberry }\end{array}$ & Fragaria virginiana & Odemin \\
\hline Eastern cottontail & Sylvilagus floridanus & Waabooz \\
\hline Eastern wolf & Canis lupus & Maengun \\
\hline Fisher & Martes pennanti & \\
\hline Lake herring & Coregonus artedii & Okeyawis \\
\hline Lake sturgeon & Acipenser fulvescens & Maame \\
\hline Lake trout & Salvelinus namaycush & Namegos \\
\hline Lake whitefish & Coregonus clupeaformis & Miitgookamaig \\
\hline Large mouth bass & Micrpterus salmoides & Maannashigan \\
\hline Muskellunge & Esox masquinongy & Maaskinoozhe \\
\hline $\begin{array}{l}\text { North American } \\
\text { porcupine }\end{array}$ & Erethizon dorsatum & Gawg \\
\hline Northern pike & Esox lucieus & Gidagaa-ganozhii \\
\hline Northern raccoon & Procyon lotor & Ehiban \\
\hline Pickerel/walleye & Sander vitreus & Ogaa \\
\hline Pine marten & Martes martes & Wabizhashi \\
\hline Rainbow smelt & Osmerus mordax & Biijimaagozens \\
\hline Rainbow trout & Oncorhynchus mykiss & Namegoshens \\
\hline Red fox & Vulpes vulpes & Miskwaawaagosh \\
\hline River otter & Lutra canadensis & Nigig \\
\hline Ruffed grouse & Bonasa umbellus & Bine \\
\hline Small mouth bass & Micrpterus dolomieu & Ashigan \\
\hline Snowshoe hare & Lepus americanus & Waabooz \\
\hline Splake & $\begin{array}{l}\text { Salvelinus namaycush } X \\
\text { Salvelinus fontinalis }\end{array}$ & \\
\hline Striped skunk & Mephitis mephitis & Zhigaag \\
\hline Sucker spp. & Catostomus spp. & Namebin \\
\hline Sweet-flag & Acorus americanus & Weekah \\
\hline White-tailed deer & Odocoileus virginianus & Wawashkeshshi \\
\hline Wild leek & Allium tricoccum & \\
\hline Yellow perch & Perca flavescens & Ashigan \\
\hline
\end{tabular}

Appendix 2 Preliminary survey used to identify Knowledge Holders about wild harvest/management from the Chippewas of Nawash Unceded First Nation community

Rationale

This survey is designed to systematically identify those persons who possess knowledge of traditional Aboriginal practices and/or stories pertaining to the harvesting of wild populations, including fish and wild.

Section A

In section A please identify the one person from your community who you feel is most knowledgeable for each of the numbered topics (1 through 4 ). Please note that you may identify persons who are originally from your community but who reside elsewhere because of intermarriage or other personal reasons. If you do choose to identify persons living outside of your community please indicate this in brackets beside their name and where possible include the name of the community in which they reside.

1. The use of spiritual practices such as prayer and offerings in relation to the harvesting of wild populations including fish and wild.

2. Traditional techniques or practices for harvesting whitefish, trout, suckers, etc.

3. Traditional techniques or practices for harvesting wild such as deer, moose, beaver, bear, muskrat, etc.

4. Stories about the harvesting of wild populations including fish and wild.

\section{Section B}

In section $\mathrm{B}$, identify up to five persons from your community who you feel are knowledgeable for each of the numbered topics (1 through 4 ). Please note that you may identify persons who are originally from your community but who reside elsewhere because of intermarriage or other personal reasons. If you do choose to identify persons living outside of your community please indicate this in brackets beside their name and where possible include the name of the community in which they reside.

1. The use of spiritual practices such as prayer and offerings in relation to the harvesting of wild populations including fish and wild.

2. Traditional techniques for harvesting whitefish, trout, suckers, etc.

3. Traditional techniques or practices for harvesting wild such as deer, moose, beaver, bear, muskrat, etc.

4. Stories about the harvesting of wild populations including fish and wild. 
Appendix 3 Guide for Initial and Follow-up semistructured interviews with Chippewas of Nawash Unceded First Nation Knowledge Holders regarding traditional Ojibway principles of wild harvest/management

\section{Initial Interview}

1. How did you make a living in the old days?

2. How did you store food before you had electricity?

3. What types of animals were hunted?

4. Were there animals that people did not hunt? If so, why?

5. What kinds of fish were caught?

6. What principles guided you when you were hunting or fishing?

7. How did you know how much to take?

8. How did you know when to hunt and when not to?

9. How did you know when to fish and when not to?

10. How were you taught how to hunt and fish?

11. Did people share stories with one another about hunting and fishing? If so, what kinds of knowledge were exchanged?

12. What were the fish huts at the Cove of Cork used for?

13. Did people make offerings or pray before they went out to hunt or fish?

14. Did people give thanks after they returned from hunting and fishing?

15. What is the meaning and importance of the clans?

16. Can you tell me about the Ojibway belief about creation?

17. Has the loss of the Ojibway language changed what knowledge is passed on? If so, how?

Follow-up Interview

1. The following harvest and management principles arose during the Initial interviews conducted with Nawash Knowledge Holders:

- Take only what you need

- Share with the community

- Give thanks

- Acknowledge your relationship to that which has offered itself to you

- Obey the seasons

2. Is there anything that you would like to add, change in any way, or elaborate about?

\section{References}

Akiwenzie, R., and Roote, R. (2004). Jumping to conclusions: GLFC, conflict of interest and the problem of stocking exotic salmon in the Great Lakes. A Saugeen Ojibway discussion paper presented at the IAGLR (International Association for Great Lakes Research) 2004 Conference, 24-28 May 2004, University of Waterloo, Waterloo, Ontario. http://www.saugeenojibway. ca/fisheries Accessed 28 November 2004.

Alcorn, J. B. (1993). Indigenous peoples and conservation. Conservation Biology 7: 424-426.

Allchin, D. (1999). Values in science: an educational perspective. Science Education 8(1): 1-12.

Atleo (Umeek), E. R. (2011). Principles of Tsawalk: an Indigenous approach to global crisis. UBC Press, University of British Columbia, Vancouver, British Columbia, Canada. 202 pp.

Ayers, C. A. (2005). Marine conservation from a First Nations' perspective: a case study of the principles of the Hul'qumi'num of Vancouver Island, British Columbia. M.Sc. Thesis, Interdisciplinary Studies, University of Victoria, Victoria, British Columbia, Canada, 190pp.

Barsh, R. L., and Youngblood Henderson, J. (2003). Biodiversity and Canada's Aboriginal peoples. In Jentoft, S., Minde, H., and Nilsen, R. (eds.), Indigenous People: Resource Management and Global Rights. Eburon Academic Publishers, Delft, Netherlands, pp. 45-66.

Berkes, F. (1999). Sacred ecology: traditional ecological knowledge and resource management. Taylor and Francis, Philadelphia, Pennsylvania, USA.

Berkes, F., Kislalioglu, M., Folke, C., and Gadgil, M. (1998). Exploring the basic ecological unit: ecosystem-like concepts in traditional societies. Ecosystems 1: 409-415.

Bilbao, B. A., Leal, A. V., and Méndez, C. L. (2010). Indigenous use of fire and forest loss in Canaima National Park, Venezuela. Assessment of and tools for alternative strategies of fire management in Pemón Indigenous lands. Human Ecology 38: 663-673.

Bjørklund, I. (1990). Sámi reindeer pastoralism as an indigenous resource management system in northern Norway: a contribution to the common property debate. Development and Change 21: 75-86.

Blair, P. J. (1997). Solemn promises and solum rights: the Saugeen Ojibway fishing grounds and $R$. v. Jones and Nadjiwon. Ottawa Law Review 28: 125-143.

Blair, P. (2000). Taken for "granted": Aboriginal title and public fishing rights in Upper Canada. Ontario History 92: 31-55.

Borrows, J. (1997). Living between water and rocks: First Nations, environmental planning and democracy. University of Toronto Law Journal 417.

Botsford, L. W., Micheli, F., and Hastings, A. (2003). Principles for the design of marine reserves. Ecological Applications, 13(1) Supplement, 2003, pp. S25-S31.

Brant Castellano, M. (2004). Ethics of Aboriginal research. Journal of Aboriginal Health 1: 98-114.

Brightman, R. (1987). Conservation and resource depletion: the case of Boreal Forest Algonquians. In McKay, B. J., and Acheson, J. M. (eds.), The Question of the Commons: The Culture and Ecology of Communal Resources. University of Arizona Press, Tucson, Arizona, USA, pp. 121-141.

Brightman, R. A. (1993). Grateful prey: Rock Cree human-animal relationships. University of California Press, Berkeley, California, USA. 396 pp.

Brightman, R. (2007). Nature and culture in the bush: a nature/culture metalanguage and Rock Cree parallels. In Laugrand, F. B., and Oosten, J. G. (eds.), La nature des esprits dans les cosmologies autochtones (Nature of spirits and spirits of nature in Aboriginal cosmologies). Les Presses de l'Université Laval, Québec, Québec, Canada, pp. 21-44.

Buijs, A. (2009). Lay people's images of nature: comprehensive frameworks of values, beliefs, and value orientations. Society and Natural Resources 22: 417-432.

Callicott, J. B. (1991). Conservation ethic and fishery management. Fisheries 16: 22-28. 
Castleden, H., Garvin, T., and Nation, H.-a.-a. F. (2009). "Hishuk Tsawak" (everything is one/connected): a Huu-ay-aht worldview for seeing forestry in British Columbia, Canada. Society and Natural Resources 22: 789-804.

Chao, A., Colwell, R. K., Lin, C.-W., and Gotelli, N. J. (2009). Sufficient sampling for asymptotic minimum species richness estimators. Ecology 90: 1125-1133.

Christensen, N. L., Baruska, A. M., Brown, J. H., Carpenter, S., D'Antonio, C., Francis, R., Franklin, J. F., MacMahon, J. A., Noss, R. F., Parsons, D. J., Peterson, C. H., Turner, M. G., and Woodmansee, R. G. (1996). The report of the Ecological Society of America Committee on the Scientific Basis for Ecosystem Management. Ecological Applications 6: 665-691.

Clark, D. A., and Slocombe, D. S. (2009). Respect for grizzly bears: an Aboriginal approach for co-existence and resilience. Ecology and Society $14: 42$. online.

Colding, J., and Folke, C. (2001). Social taboos: "invisible" systems of local resource management and biological conservation. Ecological Applications 11: 584-600.

Crawford, S. S., and Morito, B. (1997). Comment: toward a definition of conservation principles for fisheries management. Canadian Journal Of Fisheries and Aquatic Sciences 54: 2720-2723.

Crawford, S., Wehkamp, C. A., and Smith, N. (2010). Translation of Indigenous/Western science perspectives on Adaptive Management for environmental assessments. Report prepared for the Research and Development Monograph Series 2009, Canadian Environmental Assessment Agency, Ottawa, Ontario, Canada. http://www.ceaa-acee.gc.ca/default.asp?lang=Enandn= 7F3C6AF0-1 65pp.

Dale, V. H., Brown, S., Haeuber, R., Hobbs, N. T., Huntley, N., Naiman, R. J., Riebsame, W. E., Turner, M. G., and Valone, T. (2000). Ecological principles and guidelines for managing the use of land. Ecological Applications 10: 639-670.

Davis, A., and Ruddle, K. (2010). Constructing confidence: rational skepticism and systematic enquiry in local ecological knowledge research. Ecological Applications 20: 880-894.

Davis, A., and Wagner, J. R. (2003). Who knows? On the importance of identifying "experts" when researching local ecological knowledge. Human Ecology 31: 463-489.

Densmore, F. (1928). Indian Use of wild plants for crafts, food, medicine, and charms. Irocrafts Ltd. Indian Publications, Ohsweken, Ontario, Canada.

Driben, P., Auger, D. J., Doob, A. N., and Auger, R. P. (1997). No killing ground: Indigenous law governing the killing of wildlife among Cree and Ojibwa of Northern Ontario. Ayaangwaamizin: The International Journal of Indigenous Philosophy 1: 90-107.

Ebbin, S. A. (2011). The problem with problem definition: mapping the discursive terrain of conservation in two Pacific salmon management regimes. Society and Natural Resources 24: 148-164.

FAO. (2001). Code of conduct for responsible fisheries. Technical guidelines for responsible fisheries No. 2. Precautionary approach to capture fisheries and species introductions. Part 6: Precautionary approach to species introduction. Food and Agriculture Organization, United Nations, pp. 29-36.

Feit, H. A. (1986). James Bay Cree Indian management and moral considerations of fur-bearers. In Native People and Renewable Resource Management, The 1986 Symposium of the Alberta Society of Professional Zoologists, Edmonton, Alberta, Canada, pp. 49-65.

Feit, H. A. (1987). Waswanipi Cree management of land and wildlife: Cree cultural-ecology revisited. In Cox, B. A. (ed.), Native Peoples, Native Lands: Canadian Indians, Inuit and Metis. Carleton University Press, Ottawa, Ontario, Canada, pp. 75-91.

Feit, H. (1994). Dreaming of animals: the Waswanipi Cree shaking tent ceremony in relation to environment, hunting and missionization. In Iromoto, T., and Yamada, T. (eds.), Circumpolar Religion and
Ecology: Anthropology of the North. University of Tokyo Press, Tokyo, Japan, pp. 289-316.

Fowler, C. W. (2003). Tenets, principles, and criteria for management: the basis for systemic management. Marine Fisheries Review 65: 1-55.

Francis, R. C., Hixon, M. A., Clarke, M. E., Murawski, S. A., and Ralston, S. (2007). Ten commandments for ecosystem-based fisheries scientists. Fisheries 32: 217-233.

FSC (1996). FSC international standard: FSC principles and criteria for forest stewardship (Amended 2002). Report FSC-STD-01-001, version 4-0. Forest Stewardship Council, Bonn, Germany. 13pp.

González-Laxe, F. (2005). The precautionary principle in fisheries management. Marine Policy 29: 494-505.

Green, D., and Raygorodetsky, G. (2010). Indigenous knowledge of a changing climate. Climatic Change 100(2): 239-242.

Grenier, L. (1998). Working with Indigenous knowledge: a guide for researchers. IDRC, Ottawa, Ontario, Canada.

Hallowell, A. I. (1955). Culture and experience. Schocken Books, New York, New York, USA.

Heissenbuttal, A. E. (1996). Ecosystem management-principles for practical application. Ecological Applications 6: 730-732.

Hallowell, A. I. (1960). Ojibwa ontology, behavior, and world view. Reprinted From Diamond, S. (ed.) Culture in History: Essays in Honour of Paul Radin. In Tedlock, D., and Tedlock, B. (eds.), Teachings from the American Earth: Indian Religion and Philosophy. Liveright, New York, New York, USA, pp. 141-178.

Harris, S. (2010). The moral landscape: how science can determine human values. Free Press, New York, New York, USA.

Holt, S. J., and Talbot, L. M. (1978). New principles for the conservation of wild living resources. Wildlife Monographs 59.

Horstman, M., and Wightman, G. (2001). Karparti ecology: recognition of Aboriginal ecological knowledge and its application to management in north-western Australia. Ecological Management and Restoration 2: 99-109.

Houde, N. (2007). The six faces of traditional ecological knowledge: challenges and opportunities for Canadian co-management arrangements. Ecology and Society 12(2): 34. online.

Huntington, H. P. (1998). Observations on the utility of the semidirective interview for documenting traditional ecological knowledge. Arctic 51: 237-242.

Ingold, T. (2000). The perception of the environment: essays on livelihood, dwelling and skill. Routledge, London, England. 465pp.

Ingold, T., and Kurtilla, T. (2000). Perceiving the environment in Finnish Lapland. Body and Society 6(3-4): 183-196.

Johnston, B. (1976). Ojibway heritage. McClelland and Stewart, Toronto, Ontario, Canada.

Johnston, B. (1995). The Manitous: the spiritual world of the Ojibway. Key Porter Books, Toronto, Ontario, Canada.

Jones, R., Rigg, C., and Lee, L. L. J. (2010). Haida marine planning: First Nations as a partner in marine conservation. Ecology and Society 15: 12. online.

Keeshig-Tobias, P. (1996). The illustrated history of the Chippewas of Nawash. Chippewas of Nawash First Nation, Wiarton, Ontario, Canada.

Kendrick, A., and Manseau, M. (2008). Representing traditional knowledge: resource management and Inuit knowledge of barren-ground caribou. Society and Natural Resources 21: 404 418.

Knudtson, P., and Suzuki, D. (1992). Wisdom of the elders. Stoddart Publishing Co. Limited, Toronto, Ontario, Canada.

Koenig, E. C. (2005). Cultures and ecologies: a native fishing conflict on the Saugeen-Bruce Peninsula. University of Toronto Press, Toronto, Ontario, Canada.

Lauck, T., Clark, C. W., Mangel, M., and Munro, G. R. (1998). Implementing the precautionary principle in fisheries management through marine reserves. Ecological Applications, 8(1) Supplement, 1998, pp. S72-S78. 
Lindenmayer, D. B., and Nix, H. A. (1993). Ecological principles for the design of wildlife corridors. Conservation Biology 7: 627-630.

Lytwyn, V. P. (1990). Ojibwa and Ottawa fisheries around Manitoulin Island: historical and geographical perspectives on Aboriginal and Treaty fishing rights. Native Studies Review 6: 1-30.

Lytwyn, V. P. (1992). The usurpation of Aboriginal fishing rights: a study of the Saugeen Nation's Fishing Islands in Lake Huron. In Hodgins, B. W., Heard, S., and Milloy, J. S. (eds.), Co-existence? Studies in Ontario-First Nations Relations. Frost Center for Candian Heritage and Development Studies, Trent University, Peterborough, Ontario, pp. 81-103.

Lyver, P. O., Jones, C. J., and Doherty, J. E. (2009). Flavor or forethought: Tuhoe traditional management strategies for the conservation of kereru (Hemiphaga novaeseelandiae novaeseelandiae) in New Zealand. Ecology and Society 14: 40. online.

Mangel, M., Talbot, L. M., Meffe, G. K., Agardy, M. T., Alverson, D. L., Barlow, J., Botkin, D. B., Budowski, G., Clark, T., Cooke, J., Crozier, R. H., Dayton, P. K., Elder, D. L., Fowler, C. W., Funtowicz, S., Giske, J., Hofman, R. J., Holt, S. J., Kellert, S. R., Kimball, L. A., Ludgwig, D., Magnusson, K., Malayang III, B. S., Mann, C., Norse, E. A., Northridge, S. P., Perrin, W. F., Perrings, C., Norse, E. A., Northridge, S. P., Perrin, W. F., Perrings, C., Peterman, R. M., Rabb, G. B., Regier, H. A., Reynolds III, J. E., Sherman, K., Sissenwine, M. P., Smith, T. D., Starfield, A., Taylor, R. J., Tillman, M. F., Toft, C., Twiss Jr., J. R., Wilen, J., and Young, T. P. (1996). Principles for the conservation of wild living resources. Ecological Applications 6: 338-362.

Marsden, M., and Henare, T. A. (1992). Kaitiakitanga: a definitive introduction to the holistic world view of the Māori. A paper published in "The Woven Universe, Selected writings of Rev. Māori Marsden" Te Wananga-o-Raukawa, Otaki.

McClellan, C. (1975). My Old People Say, an ethnographic survey of southern Yukon Territory. National Museum of Man, Ottawa, Ontario, Canada.

McGregor, D. (2004). Coming full circle: Indigenous knowledge, environment, and our future. American Indian Quarterly 28: 385-410.

Menzies, C. R., and Butler, C. (2006). Introduction: understanding ecological knowledge. In Menzies, C. R. (eds.), Traditional ecological knowledge and natural resource management. University of Nebraska Press, pp. 1-17.

Metallic, F. (2008). Strengthening our relations in Gespe'gewa'gi, the Seventh District of Mi'gma'gi. In Simpson, L. R. (ed.), Lighting the Eighth Fire: The Liberation, Resurgence, and Protection of Indigenous Nations. Arbeiter Ring Publishing, Winnipeg, Manitoba, Canada, pp. 59-71.

Moller, H., Lyver, P. O. B., Bragg, C., Newman, J., Clucas, R., Fletcher, D., Kitson, J., McKechnie, S., Scott, D., and Body, R. T. I. A. (2009). Guidelines for cross-cultural Participatory Action Research partnerships: a case study of a customary seabird harvest in New Zealand. New Zealand Journal of Zoology 36: 211-241.

Morito, B. (1999). The rule of law and Aboriginal Rights: the case of the Chippewas of Nawash. Canadian Journal of Native Studies 19: $263-288$.

Morito, B. (2002). Thinking ecologically: environmental thought, values, and policy. Fernwood Publishing, Halifax, Nova Scotia, Canada.

MSC (2010). MSC fishery standard: principles and criteria for sustainable fishing. Marine Stewardship Council, London, UK. Version 1.1, 01 May 2010. 8pp.

Nadasdy, P. (2005). Transcending the debate over the ecologically noble Indian: Indigenous peoples and environmentalism. Ethnohistory 52: 291-331.

Naiman, R. J., and Latterell, J. J. (2005). Principles for linking fish habitat to fisheries management and conservation. Journal of Fish Biology 67(Supplement B): 166-185.
Nakashima, D. J. (1993). Astute observers on the sea ice edge: Inuit knowledge as a basis for Arctic co-management. In Inglis, J. T. (ed.), Traditional Ecological Knowledge: Concepts and Cases. International Development Research Centre, Ottawa, Ontario, Canada.

Overholt, T. W., and Callicott, W. (1982). Clothed-in-fur and other tales: an introduction to an Ojibwa world view. UP of America, Lanham, Maryland, USA.

Peloquin, C., and Berkes, F. (2009). Local knowledge, subsistence harvests, and social-ecological complexity in James Bay. Human Ecology 37: 533-545.

Pentland, B. T. (1995). Information systems and organizational learning: the social epistemology of organizational knowledge systems. Accounting, Management and Information Technologies 5: $1-21$.

Prober, S. M., O'Connor, M. H., and Walsh, F. J. (2011). Australian Aboriginal peoples' seasonal knowledge: a potential basis for shared understanding in environmental management. Ecology and Society $16: 12$. online.

Ratner, N. C., and Holen, D. L. (2007). Traditional ecological knowledge: applying principles of sustainability to wilderness resource management. USDA Forest Service Proceedings RMRS-P-49. 2007.

Resnik, D. B. (1998). The ethics of science: an introduction. Routledge, New York, New York, USA.

Rollin, B. E. (2006). Science and ethics. Cambridge University Press, Cambridge, UK.

Santiago-Rivera, A. L., Morse, G. S., Hunt, A., and Henry Lickers, H. (1998). Building a community-based research partnership: lessons from the Mohawk Nation of Akwesasne. Journal of Community Psychology 26: 163-174.

Schnarch, B. (2004). Ownership, control, access, and possession (OCAP) or self-determination applied to research: a critical analysis of contemporary First Nations research and some options for First Nations communities. Journal of Aboriginal Health 1: 80 95.

Shelton, P. A., and Sinclair, A. F. (2008). It's time to sharpen our definition of sustainable fisheries management. Canadian Journal of Fisheries and Aquatic Sciences 65: 2305-2314.

Sillitoe, P., Dixon, P., and Barr, J. (2005). Indigenous knowledge inquiries: a methodologies manual for development. Indigenous knowledge and development series. ITDG Publishing, Bourton Hall, Rugby, UK.

Slattery, B. (2005). Aboriginal rights and the honour of the Crown. Supreme Court Law Review 29: 433-445.

Smith, L. T. (1999). Decolonizing methodologies: research and Indigenous peoples. University of Otago Press, Dunedin, New Zealand.

Tanner, A. (1979). Bringing home animals: religious ideology and mode of production of the Mistassini Cree hunters. C. Hurst \& Company, London, UK.

Tanner, A. (2007). The nature of Quebec Cree animist practices and beliefs. In Laugrand, F. B., and Oosten, J. G. (eds.), La nature des esprits dans les cosmologies autochtones (Nature of spirits and spirits of nature in Aboriginal cosmologies). Les Presses de l'Université Laval, Québec, Québec, Canada, pp. 133-150.

Teller, E. (1998). Science and morality. Science 280(5367): 1200 1201.

Tikina, A. V., Innes, J. L., Trosper, R. L., and Larson, B. C. (2010). Aboriginal peoples and forest certification: a review of the Canadian situation. Ecology and Society 15: 33. online.

Tilman, D. (1999). The ecological consequences of changes in biodiversity: a search for general principles. Ecology 80: 1455-1474.

Turner, N. J., and Berkes, F. (2006). Coming to understanding: developing conservation through incremental learning in the Pacific Northwest. Human Ecology 34: 495-513. 
Turner, N. J., and Clifton, H. (2009). "It's so different today": Climate change and Indigenous lifeways in British Columbia, Canada. Global Environmental Change 19(2): 180-190.

Turner, N. J., Ignace, M. B., and Ignace, R. (2000). Traditional ecological knowledge and wisdom of aboriginal peoples in British Columbia. Ecological Applications 10: 1275-1287.

Utne, I. B. (2006). Systems engineering principles in fisheries management. Marine Policy 30: 624-634.

Walters, J. R. (1991). Application of ecological principles to the management of endangered species: the case of the reccockaded woodpecker. Annual Review of Ecology and Systematics 22: 505-523.

Walters, M. D. (1998). Aboriginal rights, Magna Carta and exclusive rights to fisheries in the waters of Upper Canada. Queens Law Journal 23: 301-369.
Warren, W. W. (1885). History of the Ojibway people, vol. 5. Collections of the Minnesota Historical Society, St. Paul, Minnesota, USA. reprinted 1984 Minnesota Historical Society, pp.411.

Watson, A., Matt, R., Knotek, K., Williams, D. R., and Yung, L. (2011). Traditional wisdom: protecting relationships with wilderness as a cultural landscape. Ecology and Society 16: 36 . online.

Watson-Verran, H., and Turnbull, D. (1995). Science and other Indigenous knowledge systems. In Jasanoff, S., Markle, G. E., Petersen, J. C., and Pinch, T. (eds.), Handbook of Science and Technology Studies, Revisedth ed. Sage Publishing, Thousand Oaks, California, USA, pp. 115-139.

Zavaleta, E. (1999). The emergence of waterfowl conservation among Yup'ik hunters in the Yukon-Kuskokwim Delta, Alaska. Human Ecology 27: 231-266. 